\title{
No DNA Copy Number Changes in Osteochondromas: A Comparative Genomic Hybridization Study
}

\author{
Marcelo L. Larramendy, Julio Valle, Maija Tarkkanen, \\ Aarne H. Kivioja, Erkki Karaharju, Tarja Salmivalli, \\ Inkeri Elomaa, and Sakari Knuutila
}

\begin{abstract}
Cytogenetic changes in osteochondroma samples were studied by comparative genomic hybridization and by chromosome banding. No DNA copy number changes (15 patients) or chromosomal aberrations (9 patients) were observed in any of the patients. (C) Elsevier Science Inc., 1997
\end{abstract}

\section{INTRODUCTION}

Osteochondroma (OC) or osteocartilaginous exostosis is a benign cartilaginous tumor with a controversial pathogenesis [1-3]. About $90 \%$ of osteochondromas arise in the long bones of the limbs in the vicinity of metaphyses. Although most of the OCs are sporadic and solitary, multiple lesions are seen in 2 rare autosomal dominant disorders: hereditary multiple exostoses syndrome and LangerGiedion syndrome, also called tricho-rhino-phalangeal syndrome type II [4]. The OCs of these syndromes are histopathologically indistinguishable from sporadic tumors, but are more prone to transform into chondrosarcomas [5].

Cytogenetic data on OC is sparse, but a limited number of OCs have a deletion in $8 \mathrm{q}[6,7]$. Patients with hereditary multiple exostoses syndrome or Langer-Giedion syndrome have constitutional chromosomal rearrangements at $8 \mathrm{q} 24$, a region linked to hereditary multiple exostoses $[8,9]$. Linkage studies have identified 3 chromosomal locations for the hereditary multiple exostoses syndrome at $8 \mathrm{q} 24.1$ (EXT1), the pericentromeric region of chromosome 11 (EXT2), and at 19p11-p13 (EXT3) [9-12]. Loss of heterozygosity has been reported with markers linked to EXT1 and EXT2 in both sporadic chondrosarcomas and

From the Department of Medical Genetics, Haartman Institute, University of Helsinki, Finland [M. L. L., M. T., S. K.]; the Laboratory of Cytogenetics and Cytology, Faculty of Natural Sciences, National University of La Plata, Argentina [M. L. L.]; Department of Pathology, Haartman Institute, University of Helsinki, Finland [J. V.]; Department of Orthopaedics and Traumatology, Helsinki University Central Hospital, Helsinki, Finland [A. H. K., E. K.]; Department of Radiology, Helsinki University Central Hospital, Helsinki, Finland [T. S.J; Department of Oncology, Hel-sinki University Central Hospital, Helsinki, Finland [I. E.]. Address reprint requests to: Sakari Knuutila, Ph.D., Department of Medical Genetics, Haartman Institute, P.O. Box 21 (Haartmaninkatu 3), FIN-00014 University of Helsinki, Finland. Received July 2, 1996; September 20, 1996. chondrosarcomas derived from multiple exostoses [9-13]. Thus, it has been suggested that EXT genes have tumorsuppressor properties or are indeed tumor-suppressor genes $[12,14]$.

CGH offers the possibility to detect DNA sequence copy number changes in tumors without specific probes and/or previous knowledge of the chromosomal rearrangements [15]. In the present study we have adopted CGH to detect gains and losses of DNA sequences in 15 osteochondromas. Chromosome banding analysis also was performed on 9 tumors.

\section{MATERIAL AND METHODS}

The material for CHG comprised 15 primary OC samples obtained from 15 patients treated at the Department of Orthopaedics and Traumatology, Helsinki University Central Hospital (Table 1). The maximum thickness of the cartilaginous cap was measured in perpendicular hematoxylin and eosin-stained sections. The tumor specimens, used for the DNA extraction according to standard methods, contained in general tissue from the cap and the stalk. For tumor specimens of patients $1,2,4-8,12$, and 13 , conventional chromosome banding analysis was performed after shortterm (1-21 days) culture [16].

CGH was performed using direct fluorochrome-conjugated DNAs for all samples according to the protocol described elsewhere $[15,17]$ with minor modifications.

The hybridizations were analyzed using an Olympus fluorescence microscope and the ISIS digital image analysis system (MetaSystems GmbH, Altlussheim, Germany) based on an integrated high-sensitivity monochrome CCD camera and automated CGH analysis software. Three-color images (red [Texas red] for the reference DNA, green [FITC] for the tumor DNA, and blue [DAPI] for the chromosome counterstain) were obtained from 12 metaphases from each sample. DNA copy number changes were confirmed using 
Table 1 Clinical characteristics of the 15 osteochondromas analyzed by comparative genomic hybridization $^{a}$

\begin{tabular}{|c|c|c|c|c|}
\hline Sample number & Sex $_{\text {age }}^{b}$ & Tumor location & Tumor size & $\begin{array}{l}\text { Thickness of the } \\
\text { cartilage cap (cm) }\end{array}$ \\
\hline 1 & $\mathrm{M}, 21$ & Fibula & $4.6 \times 4.4 \times 5.7$ & 0.4 \\
\hline 2 & $\mathrm{M}, 24$ & Tibia & $4.0 \times 2.0 \times 1.0$ & 0.2 \\
\hline 3 & $\mathrm{M}, 14$ & Femur & NA & 0.4 \\
\hline 4 & $\mathrm{M}, 17$ & Tibia & $5.0 \times 3.0 \times 3.0$ & 0.4 \\
\hline 5 & $\mathrm{M}, 46$ & Hand & $1.3 \times 1.0 \times 1.0$ & 0.1 \\
\hline 6 & $\mathrm{M}, 15$ & Femur & NA & 0.3 \\
\hline 7 & $\mathrm{M}, 17$ & Femur & $1.7 \times 0.7 \times 0.5$ & 0.9 \\
\hline 8 & $\mathrm{~F}, 14$ & Humerus & $8.0 \times 2.5 \times 2.5$ & 0.7 \\
\hline 9 & $\mathrm{~F}, 28^{c}$ & Scapula & NA & 0.5 \\
\hline 10 & $\mathrm{M}, 57^{c}$ & Femur & $12.0 \times 7.5 \times 8.5$ & 2.0 \\
\hline 11 & M, 32 & Femur & $6.0 \times 8.0 \times 5.0$ & 1.5 \\
\hline 12 & $M, 19$ & Femur & NA & 0.3 \\
\hline 13 & $\mathrm{M}, 28^{c}$ & Femur & $10.0 \times 6.0 \times 6.0$ & 0.5 \\
\hline 14 & $\mathrm{M}, 31$ & Scapula & $6.0 \times 5.0 \times 2.5$ & 0.6 \\
\hline 15 & M, 37 & Tibia & NA & 0.5 \\
\hline
\end{tabular}

Abbreviations: $\mathrm{F}$, female; $\mathrm{M}$, male.

${ }^{a}$ Tumors 1, 2, 4-8, 12, and 13 had normal karyotypes after conventional G-banding analysis.

${ }^{b}$ Age in years at diagnosis.

${ }^{c}$ Hereditary multiple exostoses.

a confidence interval of $99 \%$ with a $1 \%$ error probability. In each CGH experiment, negative (peripheral blood DNA from normal donors) and positive (tumor DNA with known copy number changes) controls were included and run simultaneously with the tumor samples.

\section{RESULTS AND DISCUSSION}

The present study is the first report of CGH performed on osteochondromas. None of the 15 OC samples showed any amplifications or losses of DNA sequences by CGH. These negative $\mathrm{CGH}$ findings are well in line with our normal results from karyotype analysis.

Earlier karyotype analyses by others have demonstrated deletions of the distal part of $8 \mathrm{q}$, but only a very limited number of tumor cases have been reported so far [6, 7]. In the present study no changes were detected at $8 \mathrm{q} 24$. As both CGH and chromosome banding are rough techniques that reveal only genetic changes of megabases, it still is possible that 8q24 or other chromosomal areas contain loss of heterozygosity or gene mutations, such as the frameshift mutation reported by Ahn et al. [14].

This study was supported by the Sigrid Jusélius Foundation, the Clinical Research Institute of the Helsinki University Central Hospital, the Finnish Cancer Society, and the Foundation of Orthopaedics and Traumatology, all from Finland, and from the National Council of Scientific and Technological Research (CONICET') and the National University of La Plata, from Argentina.

\section{REFERENCES}

1. Milgran JR (1983): The origins of osteochondromas and enchondromas. Clin Orthop Rel Res 174:264-284.
2. Langenskiold A (1947): Normal and pathological bone growth in the light of the development of cartilaginous foci in chondrodysplasia. Acta Chir Scand 95:367-372.

3. Klumper A (1977): Intraosseous angiography in the investigation of the pathogenesis of osteochondromas. Fortschr Geb Röntgenstr Nuklearmed Ergänzungsband 127:142-145.

4. McKusick VA (1994): Mendelian Inheritance in Man, ed 11, Johns Hopkins University Press, Baltimore.

5. Campanacci M (1990): Bone and Soft Tissue Tumors, Springer Verlag, New York.

6. Bridge JA, Bhatia PS, Anderson JR, Neff JR (1993): Biologic and clinical significance of cytogenetic and molecular cytogenetic abnormalities in benign and malignant cartilaginous lesions. Cancer Genet Cytogenet 69:79-90.

7. Mertens F, Rydholm A, Kreicbergs A, Willén H, Jonsson $K$, Heim S, Mitelman F, Mandahl N (1994): Loss of chromosome band 8q24 in sporadic osteocartilaginous exostoses. Genes Chromosom Cancer 9:8-12.

8. Lüdecke H-J, Johnson C, Wagner MJ, Wells DE, Turleau C, Tommeup N, Latos-Bielenska A, Sandig K-R, Meinecke P, Zabel B, Horsthemke B (1991): Molecular definition of the shortest region of deletion overlap in the Langer-Giedion syndrome. Am J Hum Genet 49:1197-1206.

9. Cook A, Raskind W, Halloran-Blanton S, Pauli RM, Gregg RG, Francomano CA, Puffenberger E, Conrad EU, Schmale G, Schellenberg G, Wijsman E, Hecht JT, Wells D, Wagner M) (1993): Genetic heterogeneity in families with hereditary multiple exostoses. Am J Hum Genet 53:71-79.

10. Wu Y-Q, Heutink P, de Vries BBA, Sandkuijl LA, van den Ouweland AMW, Niermeijer MF, Galjaard H, Reyniers E, Willems PJ, Halley DJJ (1994): Assignment of a second locus for multiple exostoses to the pericentromeric region of chromosome 11. Hum Mol Genet 3:167-171.

11. Le Merrer M, Legeai-Mallet L, Jeannin PM, Horsthemke B, Schinzel A, Plauchu H, Toutain A, Achard F, Munnich A, Maroteaux P (1994): A gene for hereditary multiple exostoses maps to chromosome 19p. Hum Mol Genet 3:717-722.

12. Hecht JT, Hogue D, Strong LC, Hansen MF, Blanton SH, Wagner M (1995): Hereditary multiple exostosis and chondrosar- 
coma: Linkage to chromosome 11 and loss of heterozygosity for EXT-linked markers on chromosomes 11 and 8. Am J Hum Genet 56:1125-1131.

13. Raskind WH, Conrad EU, Chansky H, Matsushita M (1995): Loss of heterozygosity in chondrosarcomas for markers linked to hereditary multiple exostoses loci on chromosomes 8 and 11. Am J Hum Genet 56:1132-1139.

14. Ahn J, Lüdecke H-J, Lindow S, Horton WA, Lee B, Wagner MJ, Horsthemke B, Wells DE (1995): Cloning of the putative tumour suppressor gene for hereditary multiple exostoses (EXT1). Nature Genet 11:137-143.

15. Kallioniemi A, Kallioniemi O-P, Sudar D, Rutovitz D, Gray
JW, Waldman F, Pinkel D (1992): Comparative genomic hybridization for molecular cytogenetic analysis of solid tumors. Science 258:818-821.

16. Tarkkanen M, Kaipainen A, Karaharju E, Böhling T, Szymanska J, Heliö H, Kivioja A, Elomaa I, Knuutila S (1993): Cytogenetic study of 249 consecutive patients examined for a bone tumor. Cancer Genet Cytogenet 68:1-21.

17. Larramendy ML, Tarkkanen M, Valle J, Kivioja AH, Ervasti H, Karaharju E, Salmivalli T, Elomaa I, Knuutila S (1997): Gains, losses, and amplifications of DNA sequences evaluated by comparative genomic hybridization in chondrosarcomas. Am J Pathol 150:685-691. 